University of Nebraska - Lincoln

DigitalCommons@University of Nebraska - Lincoln

\title{
Microbial production of isotopically light iron(II) in a modern chemically precipitated sediment and implications for isotopic variations in ancient rocks
}

G. E. Tangalos

University of Wisconsin - Madison

B. L. Beard

University of Wisconsin - Madison

C. M. Johnson

University of Wisconsin - Madison

Charles N. Alpers

U.S. Geological Survey, cnalpers@usgs.gov

E. S. Shelobolina

University of Wisconsin - Madison

See next page for additional authors

Follow this and additional works at: https://digitalcommons.unl.edu/usgsstaffpub

Part of the Earth Sciences Commons

Tangalos, G. E.; Beard, B. L.; Johnson, C. M.; Alpers, Charles N.; Shelobolina, E. S.; Xu, H.; Konishi, H.; and Roden, E. E., "Microbial production of isotopically light iron(II) in a modern chemically precipitated sediment and implications for isotopic variations in ancient rocks" (2010). USGS Staff -- Published Research. 481.

https://digitalcommons.unl.edu/usgsstaffpub/481

This Article is brought to you for free and open access by the US Geological Survey at DigitalCommons@University of Nebraska - Lincoln. It has been accepted for inclusion in USGS Staff -- Published Research by an authorized administrator of DigitalCommons@University of Nebraska - Lincoln. 


\section{Authors}

G. E. Tangalos, B. L. Beard, C. M. Johnson, Charles N. Alpers, E. S. Shelobolina, H. Xu, H. Konishi, and E. E. Roden

This article is available at DigitalCommons@University of Nebraska - Lincoln: https://digitalcommons.unl.edu/ usgsstaffpub/481 


\title{
Microbial production of isotopically light iron(II) in a modern chemically precipitated sediment and implications for isotopic variations in ancient rocks
}

\author{
G. E. TANGALOS, ${ }^{1}$ B. L. BEARD,${ }^{1}$ C. M. JOHNSON,${ }^{1}$ C. N. ALPERS,${ }^{2}$ E. S. SHELOBOLINA, ${ }^{1}$ \\ H. XU, ${ }^{1}$ H. KONISHI ${ }^{1}$ AND E. E. RODEN ${ }^{1}$ \\ ${ }^{1}$ Department of Geoscience and NASA Astrobiology Institute, University of Wisconsin, Madison, WI, USA \\ ${ }^{2}$ California Water Science Center, US Geological Survey, Sacramento, CA, USA
}

\begin{abstract}
The inventories and Fe isotope composition of aqueous Fe(II) and solid-phase Fe compounds were quantified in neutral-pH, chemically precipitated sediments downstream of the Iron Mountain acid mine drainage site in northern California, USA. The sediments contain high concentrations of amorphous Fe(III) oxyhydroxides $\left[\mathrm{Fe}(\mathrm{III})_{\mathrm{am}}\right]$ that allow dissimilatory iron reduction (DIR) to predominate over Fe-S interactions in Fe redox transformation, as indicated by the very low abundance of $\mathrm{Cr}$ (II)-extractable reduced inorganic sulfur compared with dilute $\mathrm{HCl}$-extractable $\mathrm{Fe}$. $\delta^{56} \mathrm{Fe}$ values for bulk $\mathrm{HCl}$ - and $\mathrm{HF}$-extractable Fe were $\approx 0$. These near-zero bulk $\delta^{56} \mathrm{Fe}$ values, together with the very low abundance of dissolved Fe in the overlying water column, suggest that the pyrite Fe source had near-zero $\delta^{56} \mathrm{Fe}$ values, and that complete oxidation of Fe(II) took place prior to deposition of the Fe(III) oxide-rich sediment. Sediment core analyses and incubation experiments demonstrated the production of millimolar quantities of isotopically light $\left(\delta^{56} \mathrm{Fe} \approx-1.5\right.$ to $-0.5 \%$ ) aqueous $\mathrm{Fe}(\mathrm{II})$ coupled to partial reduction of Fe(III) am by DIR. Trends in the Fe isotope composition of solid-associated Fe(II) and residual Fe(III) am are consistent with experiments with synthetic Fe(III) oxides, and collectively suggest an equilibrium Fe isotope fractionation between aqueous $\mathrm{Fe}(\mathrm{II})$ and $\mathrm{Fe}(\mathrm{III})_{\mathrm{am}}$ of approximately $-2 \%$. These Fe(III) oxide-rich sediments provide a model for early diagenetic processes that are likely to have taken place in Archean and Paleoproterozoic marine sediments that served as precursors for banded iron formations. Our results suggest pathways whereby DIR could have led to the formation of large quantities of low- $\delta^{56} \mathrm{Fe}$ minerals during BIF genesis.
\end{abstract}

Received 14 September 2009; accepted 6 March 2010

Corresponding author: Eric E. Roden. Tel.: +1 (608) 890-0724; fax: +1 (608) 262-0693; e-mail: eroden@ geology.wisc.edu

\section{INTRODUCTION}

Dissimilatory microbial iron reduction (DIR) is a major pathway of organic carbon oxidation in sediments where amorphous $\mathrm{Fe}(\mathrm{III})$ oxyhydroxides [ $\mathrm{Fe}(\mathrm{III})_{\mathrm{am}}$ ] are abundant (Lovley, 1991; Thamdrup, 2000). Dissimilatory ironreducing microorganisms (DIRMs) use $\mathrm{Fe}(\mathrm{III})$ as a terminal electron acceptor in anaerobic respiration, and gain energy by coupling the oxidation of organic compounds or hydrogen to the reduction of $\mathrm{Fe}$ (III) oxides (Lovley et al., 2004). DIR has been proposed as a mechanism for the generation of authigenic mineral phases (e.g. siderite and magnetite) in ancient sedimentary environments (Cloud, 1974; Walker, 1984, 1987; Lovley et al., 1987; Nealson \& Myers, 1990; Konhauser et al., 2005) that were ultimately preserved in banded iron formations (BIFs). This assertion is consistent with the presence of DIRMs in deeply branching thermophilic and hyperthermophilic prokaryotic lineages (Vargas et al., 1998; Kashefi \& Lovley, 2000, 2003; Kashefi et al., 2002).

Analysis of the stable Fe isotope composition of sedimentary rocks provides a potential means for evaluating the contribution of biotic and abiotic Fe redox cycling pathways to sediment diagenesis (Beard et al., 2003; Beard \& Johnson, 2004; Johnson et al., 2004). Recent investigations of ancient (Johnson et al., 2003, 2008b; Yamaguchi et al., 2005; Archer \& Vance, 2006; Jenkyns et al., 2007) and modern (Bergquist \& Boyle, 2006; Severmann et al., 2006, 2008; Staubwasser et al., 2006; Fehr et al., 2008; Homoky et al., 2009; Teutsch et al., 2009) sedimentary environments have explored the relationship between DIR and Fe isotopes. The potential for DIR to produce Fe isotope fractionations observed in natural environments is supported by laboratory studies (Beard et al., 
1999, 2003; Crosby et al., 2005, 2007; Johnson et al., 2005; Wu et al., 2009), which indicate that DIR can generate significant quantities of $\mathrm{Fe}$ (II) that has negative (isotopically light) $\delta^{56} \mathrm{Fe}$ values (defined as $10^{3} \times\left[\left({ }^{56} \mathrm{Fe}{ }^{54} \mathrm{Fe}\right)_{\text {sample }}\right.$ $\left.\left({ }^{56} \mathrm{Fe} /{ }^{54} \mathrm{Fe}\right)_{\mathrm{Std}}\right] /\left({ }^{56} \mathrm{Fe} /{ }^{54} \mathrm{Fe}\right)_{\mathrm{Std}}$, where $\left({ }^{56} \mathrm{Fe} /{ }^{54} \mathrm{Fe}\right)_{\text {Std }}$ is the average $\mathrm{Fe}$ isotope composition of igneous rocks (Beard et al., $2003)$ \}, generally between $-1 \%$ and $-3 \%$. These findings are consistent with a key role of DIR in early diagenesis and authigenic mineral formation in Archean and Paleoproterozoic sediments that have preserved large inventories of isotopically light Fe (Johnson et al., 2008a). However, the link between DIR and Fe isotope fractionation has not yet been demonstrated in a natural system where DIR has been shown by microbiological methods to be active in sediment metabolism.

Dissimilatory sulfate reduction (DSR) is the dominant pathway for sediment organic carbon oxidation in modern marine environments (Thamdrup, 2000), and the sulfide produced by this process reacts with sediment $\mathrm{Fe}$ to produce Fe-sulfide minerals that have near-zero or slightly positive $\delta^{56} \mathrm{Fe}$ values (Severmann et al., 2006). Extensive Fe cycling, as recorded, for example, in deposition of BIFs in the Archean and early Proterozoic could not have occurred in the presence of significant sulfide, a conclusion supported by the very low sulfide contents of BIFs (e.g. Klein, 2005). Typical modern marine sediments are thus poor analogs for evaluating the potential influence of DIR on the Fe isotope composition of Archean marine systems.

Temporal variations in the isotopic compositions of marine sedimentary rocks support the idea that DIR and DSR produced distinct isotopic fingerprints at different times during the Archean and Paleoproterozoic eras (Fig. 1). Based on average $\mathrm{Fe} / \mathrm{S}$ ratios in BIFs (Konhauser et al., 2005) compared with modern marine sediments (Berner, 1982), Fe and $S$ sequestration rates during BIF deposition were likely much higher and lower, respectively, than modern global averages. In particular, deposition of the extensive 2.5-Ga-old BIFs of the Hamersley Group (Australia) and Transvaal Supergroup (South Africa) occurred during a time of high reactive Fe flux relative to sedimentary sulfide (pyrite) sequestration, and was associated with the largest measured Fe isotope excursion in rocks and minerals known on Earth (Fig. 1A). High rates of reactive Fe flux would have favored DIR over DSR in sediment $\mathrm{Fe}$ transformations. Hence, the negative $\delta^{56} \mathrm{Fe}$ values for magnetite and siderite in BIFs, as well as pyrite in black shales, has been interpreted to reflect mobilization of large quantities of low- $\delta^{56} \mathrm{Fe}$ aqueous $\mathrm{Fe}(\mathrm{II})$ produced by DIR, reflecting a time of maximum expansion of DIR on Earth (Johnson et al., 2008a). Increases in seawater sulfate concentration in the Proterozoic led to an expansion of DSR, which resulted in the onset of low- $\delta^{34} S$ sulfide burial (Canfield, 1998; Habicht et al., 2002) (Fig. 1B) and the eventual cessation of BIF deposition (Poulton et al., 2004); an increasing importance of DSR may explain the decrease in the extent of
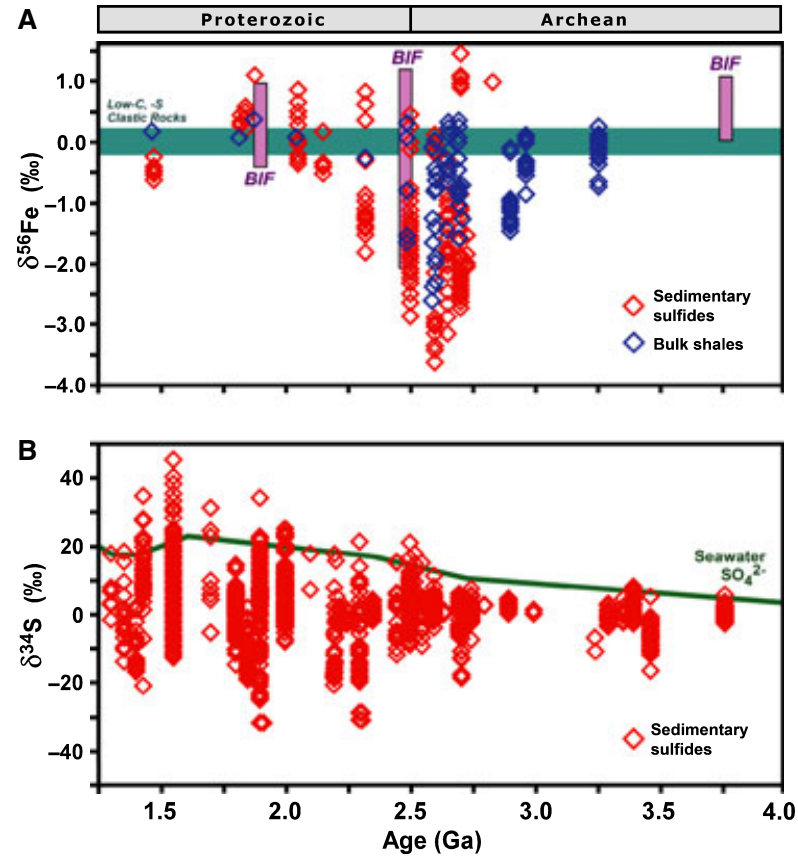

Fig. 1 Temporal variations in Fe and S isotopic compositions of marine sedimentary rocks in the Archean and Paleoproterozoic eras (modified from fig. 7 in Johnson et al. (2008a)). (A) The Fe isotope composition of banded iron formations, sedimentary sulfides, and shales has been proposed to record a period of maximum expansion of DIR at the Neoarchean-Paleoproterozoic boundary ( $\sim 2.5 \mathrm{Ga}$ ), reflected in isotopically light magnetite, siderite, and pyrite. (B) The $S$ isotope composition of sedimentary sulfides has been interpreted to record the transition from conditions favoring DIR to expansion of DSR (indicated by the increasing divergence between seawater sulfate and sedimentary sulfide $\delta^{34} S$ values). Sulfur and Fe isotope data are from Canfield (2001), Shen et al. (2001), Johnson et al. (2003, 2008b), Dauphas et al. (2004), Rouxel et al. (2005, 2006), Yamaguchi et al. (2005), Archer \& Vance (2006), Frost et al. (2007), Severmann et al. (2008), Ohmoto et al. (2006), Ono et al. (2006), Farquhar et al. (2007), Whitehouse \& Fedo (2007), and Hyslop et al. (2008).

Fe isotope fractionation in marine sediments of Paleoproterozoic age (Fig. 1A).

This study reports the results of chemical, isotopic, and microbiological analyses of chemically precipitated sediments in the Spring Creek Arm of the Keswick Reservoir (SCAKR), downstream of the Iron Mountain acid mine drainage (AMD) site in northern CA (Nordstrom \& Alpers, 1999). This work provides the first documentation of Fe isotope fractionation in a natural system where DIR activity is demonstrated using microbiological methods. These sediments represent a potential analog to early diagenetic progenitors of banded BIFs in Archean and Paleoproterozoic marine environments. The results demonstrate that DIR can produce very high (millimolar) concentrations of isotopically light (low$\delta^{56} \mathrm{Fe}$ ) dissolved $\mathrm{Fe}(\mathrm{II})$ in Fe-rich, non-sulfidic sediments. This phenomenon provides an explanation for how large quantities of mobile, low- $\delta^{56} \mathrm{Fe}$ aqueous $\mathrm{Fe}(\mathrm{II})$ could have been generated by microbial processes in Neoarchean and Paleoproterozoic marine systems, including early BIF diagenesis. 


\section{Site description}

Iron Mountain Mine (IMM) is a group of mines within Iron Mountain located in Shasta County, CA (Fig. S1). The commodities $\mathrm{Ag}, \mathrm{Au}, \mathrm{Cu}, \mathrm{Fe}, \mathrm{Zn}$, and pyrite (for production of sulfuric acid) were recovered at various times beginning in the early 1860s and terminating with open-pit mining in 1962 (Alpers et al., 2003). AMD effluent from IMM has $\mathrm{pH}$ values ranging from the extremely low $\mathrm{pH}-3.6$ within the Richmond Mine portal (Nordstrom \& Alpers, 1999) to $\mathrm{pH}+1.0$ to +4.0 in drainage tributaries such as Spring Creek (Edwards et al., 1999; Alpers et al., 2003) (Fig. S1). Total dissolved solid concentrations in the effluent can exceed $900 \mathrm{~g} \mathrm{~L}^{-1}$ (Nordstrom, 2000).

Early AMD mitigation efforts for the Upper Sacramento River watershed affected by IMM effluent involved construction of the Keswick Dam in 1950, which created the Keswick Reservoir and the Spring Creek Debris Dam that serve a barrier to AMD flowing down Spring Creek from IMM (see Fig. S1). Neutral pH water from Whiskeytown Reservoir, part of the Trinity River watershed, flows into Keswick Reservoir through the Spring Creek Power Plant. Mixing of this neutral $\mathrm{pH}$ water with Fe-rich AMD from Spring Creek has resulted in the accumulation of three piles (in excess of $260000 \mathrm{~m}^{3}$ total bulk volume) of fine-grained, $\mathrm{Fe}$ (III) oxide-rich sediment in the SCAKR (Fig. S1). Previous mineralogical characterization of SCAKR sediments via X-ray diffraction (XRD), scanning electron microscopy and Mössbauer spectroscopy identified the presence of ferrihydrite $\left[\mathrm{Fe}(\mathrm{OH})_{3}\right]$, goethite $(\alpha-\mathrm{FeOOH})$, and mineral structures similar to synthetic schwertmannite $\left[\mathrm{Fe}(\mathrm{III})_{8} \mathrm{O}_{8}(\mathrm{OH})_{6}\left(\mathrm{SO}_{4}\right)\right]$ (Nordstrom et al., 1999). The sediments have dry weight $\mathrm{Fe}$ concentrations ranging from $4 \%$ to $47 \%$ (mean $=17 \%$ ), and the pore waters are exceptionally high in aqueous $\mathrm{Fe}(\mathrm{II})\left[\mathrm{Fe}(\mathrm{II})_{\mathrm{aq}}\right]$, with concentrations ranging up to $36 \mathrm{~mm}$ (Nordstrom et al., 1999). The pore waters have $\mathrm{pH}$ values of 5.5-6.5, carbonate alkalinities of 0-3 mM, and sulfate concentrations in excess of $10 \mathrm{~mm}$ (Nordstrom et al., 1999).

It may be seen counterintuitive that an AMD environment could be an analog to Neoarchean and Paleoproterozoic marine environments, including those involved in BIF formation. It is important to stress, therefore, that the SCAKR sediments formed under circumneutral $\mathrm{pH}$ conditions, and that it is their chemical composition that makes them an appropriate model for studying biogeochemical transformations that may have taken place in ancient marine sedimentary environments. Most importantly, the SCAKR sediments contain high concentrations of reactive $\mathrm{Fe}$ (III) oxide that (as shown below) result in the predominance of DIR over DSR in early sediment diagenesis, as originally envision by Walker (1984). In addition, the high abundance of reactive $\mathrm{Fe}(\mathrm{III})$ permits generation (by DIR) of large quantities of mobile, isotopically light $\mathrm{Fe}(\mathrm{II})$. This situation differs dramatically from modern marine sediments, in which large quantities of mobile $\mathrm{Fe}(\mathrm{II})$ do not accumulate because reactive Fe becomes incorporated into iron-sulfide minerals (e.g. pyrite). Thus, this setting is envisioned to provide a snapshot of processes that occurred in the sediment pile prior to diagenetic and authigenic formation of magnetite and siderite in BIFs.

\section{MATERIALS AND METHODS}

\section{Sample collection and geochemical measurements}

Sediments from pile C of the SCAKR site (Nordstrom et al., 1999) were collected by gravity core in 2004 and 2006. Homogenized sediment from different depth intervals were placed in sealed, completely filled glass jars and stored at $4{ }^{\circ} \mathrm{C}$ prior to analysis. All samples were handled under anoxic conditions in an anaerobic chamber. Pore fluids were obtained by centrifugation $(13000 \times g, 10 \mathrm{~min})$. Iron in porewater and sediment extracts was measured colorimetrically using Ferrozine. Sulfate concentrations were determined by ion chromatography. Solid-phase Fe concentrations were determined via extractions with $0.1 \mathrm{M} \mathrm{HCl}$ and/or $0.5 \mathrm{M} \mathrm{HCl}$ (see Results and Discussion). Additional extractions were conducted to determine total reactive $\mathrm{Fe}(\mathrm{III})$ abundance $(0.2 \mathrm{~m}$ sodium citrate/ $0.35 \mathrm{M}$ acetic acid, $\mathrm{pH} 4.8$, plus $50 \mathrm{mg} \mathrm{mL}^{-1}$ sodium dithionite) and to recover crystalline $\mathrm{Fe}$ phases for $\mathrm{Fe}$ isotope analysis (7 $\mathrm{M} \mathrm{HCl}$ and $29 \mathrm{~m} \mathrm{HF}$ ). Reduced inorganic sulfide was quantified via $\mathrm{Cr}$ (II) reduction (Zhabina \& Volkov, 1978) and colorimetric sulfide analysis (Cline, 1969). A complete summary of the geochemical data is contained in Tables S1 and S2.

\section{Fe isotope analyses}

Iron isotope analyses were performed on pore water Fe, bulk sediment digests, and acid extractions using an MC-ICP-MS (multicollector, inductively coupled plasma mass spectrometer), following established protocols (Beard et al., 2003; Severmann et al., 2006). A summary of the Fe isotope data is provided in SI Table S2.

\section{Sediment incubation experiment}

Air-dried sediment from $\sim 150 \mathrm{~cm}$ depth in core 06GTIM-A was suspended $\left(28 \mathrm{~g} \mathrm{~L}^{-1}\right)$ in $10 \mathrm{~mm}$ anoxic Pipes buffer ( $\mathrm{pH}$ 6.7 ) containing $3 \mathrm{~mm}$ sodium acetate to promote $\mathrm{Fe}(\mathrm{III})$ reduction. Samples were collected periodically by needle and syringe over a 2 -month incubation period and analyzed for aqueous and solid-phase Fe abundance and isotopic composition as described earlier. The geochemical and Fe isotope data from this experiment are included in Tables S1 and S2.

\section{Microbiological analyses}

A defined mineral salts medium containing acetate and synthetic $\mathrm{Fe}(\mathrm{III})_{\text {am }}$ plus vitamins and trace minerals was used 
to enumerate DIRMs in roll-tubes with agarized medium as previously described (Shelobolina et al., 2007). The medium was buffered either at $\mathrm{pH} 6.2$ with $10 \mathrm{~mm}$ Pipes or 6.8 with $30 \mathrm{~mm} \mathrm{NaHCO}$. The roll-tubes were incubated vertically at $30^{\circ} \mathrm{C}$ for 8 weeks, after which colonies were enumerated from tubes of appropriate dilution (see Table S3). Individual colonies were transferred to liquid medium containing acetate and synthetic $\mathrm{Fe}(\mathrm{III})_{\mathrm{am}}$.

Bulk sediment DNA was extracted and purified using the Promega Wizard ${ }^{\circledR}$ Plus SV Minipreps DNA Purification System. 16S rRNA gene sequences were amplified using the universal bacterial forward primer $8 \mathrm{~F}$ and the reverse primer 1492R. PCR products were cloned using the pGEM $^{\circledR}-\mathrm{T}^{\mathrm{P}}$ vector, and sequenced at the University of Wisconsin-Madison Biotechnology Center. Nearest phylogenetic assignments (see Table S4) were made using the NCBI Basic Local Alignment Search Tool and Taxonomy Browser.

\section{RESULTS AND DISCUSSION}

\section{SCAKR sediment properties}

Measurements made on three sediment cores collected in 2004 and 2006 showed that SCAKR sediments have a relatively high $($ mean $=152$, range $=26-282$ ) ratio of non-sulfide-associated (citrate/dithionite-extractable) 'reactive $\mathrm{Fe}$ ' (Canfield, 1989) to reduced inorganic $S$ (see data in Table S1), significantly higher than most modern marine sediments (Raiswell \& Canfield, 1998), but similar to oxide- and siderite-facies BIFs from the Kuruman Iron Formation (Klein \& Beukes, 1989) and the Dales Gorge member of the Brockman Iron Formation (Ewers \& Morris, 1981). Approximately $50-100 \mathrm{mmol} \mathrm{L}^{-1}$ of $0.5 \mathrm{M} \mathrm{HCl}$-extractable $\mathrm{Fe}(\mathrm{III})_{\mathrm{am}}$ is present in SCAKR sediments (Fig. 2A); total (citrate-dithionite extractable) $\mathrm{Fe}(\mathrm{III})$ oxide concentrations are 2- to 10fold higher (see Table S1). Extended extraction of sediment in $0.5 \mathrm{M} \mathrm{HCl}$ solubilized $\sim 80 \%$ of the total reactive Fe pool (see Fig. S2). These results, along with newly collected XRD and high-resolution transmission electron microscopic analyses (see SI Figs. S3 and S4), verify the previous conclusion (Nordstrom et al., 1999) that most of the Fe(III) oxides are poorly crystalline ferrihydrite and nanocrystalline goethite phases.

The presence of comparable concentrations of $0.5 \mathrm{M} \mathrm{HCl}-$ extractable $\mathrm{Fe}(\mathrm{II})$ and $\mathrm{Fe}(\mathrm{III})$, together with the very high (several $\mathrm{mm}$ ) porewater $\mathrm{Fe}(\mathrm{II})_{\mathrm{aq}}$ values (Fig. $2 \mathrm{~A}, \mathrm{~B}$; see Table S1), indicates that DIR is active in SCAKR sediments (Lovley \& Phillips, 1987a). The large quantities of $\mathrm{Fe}(\mathrm{II})$ in the sediment must originate from internal $\mathrm{Fe}(\mathrm{III})$ reduction, given the fact that virtually all of the Fe in the aerobic, circumneutral SCAKR waters is present as colloidal Fe(III) oxide (Alpers et al., 2000). The sediments contain 1.5-4\% (dry weight) particulate organic carbon (derived from primary production in the overlying water or inputs of organic matter from the surrounding terrestrial environment), which presumably serves as the source of electron donors for DIR. Although SCAKR sediment pore fluids contain significant concentrations of sulfate (c. 4-23 mM; Fig. 2A), DIR dominates $\mathrm{Fe}$ transformation as indicated by the absence of acid volatile sulfides and the very low abundance of $\mathrm{Cr}$ (II)-extractable reduced inorganic sulfur (pyrite and/or elemental $S$ ) compared with dilute $\mathrm{HCl}$-extractable $\mathrm{Fe}$ (II) (Fig. 2B). The predominance of DIR over DSR can be attributed to the high concentration of reactive $\mathrm{Fe}$ (III) oxides, which allows DIRMs to outcompete dissimilatory sulfate-reducing bacteria for organic electron donors (Lovley \& Phillips, 1987b).

An important goal of the current study was to demonstrate the presence and activity of DIRMs through microbiological methods in the same natural samples analyzed for Fe isotope compositions. $\mathrm{Fe}(\mathrm{III})$ oxide-containing roll-tube cultures inoculated with serially diluted SCAKR sediment from $\sim 150 \mathrm{~cm}$ depth in core 06GTIM-B showed that the abundance of culturable DIRMs ranged from $10^{6}$ to $10^{7}$ cells $\mathrm{mL}^{-1}$ (see Table S3), comparable with densities observed in freshwater wetland (Roden \& Wetzel, 2002) and other aquatic sediments (Roden \& Emerson, 2007) where DIR is active. A $16 \mathrm{~S}$ rRNA gene sequence clone library from the same sediment (see Table S4) contained sequences closely related (97\% similarity) to known DIRMs (Geobacter and Geothrix). In addition, four different pure culture isolates of Geothrix fermentans (97-98\% 16S rRNA gene sequence similarity) were obtained by dilution-to-extinction methods (Shelobolina et al., 2007). These results, together with the sediment incubation experiment described below, confirm that DIRMs were active in SCAKR sediments.

\section{Sediment Fe isotope compositions}

Aqueous $\mathrm{Fe}(\mathrm{II})$ in SCAKR sediment porewater has negative $\delta^{56} \mathrm{Fe}$ values compared with bulk $\mathrm{HCl}$-extractable $\mathrm{Fe}$ (Fig. 2C). $\delta^{56} \mathrm{Fe}$ values for bulk $0.5 \mathrm{M} \mathrm{HCl}$-extractable and total hydrofluoric acid (HF)-extractable Fe fall within the range (shaded field in Fig. 2C) previously defined for terrestrial materials (Beard et al., 2003). The near-zero bulk sediment $\delta^{56} \mathrm{Fe}$ values, and the very low abundance of $\mathrm{Fe}(\mathrm{II})$ compared with total Fe in the overlying water column (Alpers et al., 2000), suggest that the pyrite Fe source had near-zero $\delta^{56} \mathrm{Fe}$ values, essentially equal to the crustal average, and that complete oxidation of $\mathrm{Fe}(\mathrm{II})$ took place in the circumneutral pH SCAKR pond prior to deposition of the Fe(III) oxide-rich sediment. This situation differs fundamentally from low-pH AMD environments, in which large variations in the $\delta^{56} \mathrm{Fe}$ values of deposited $\mathrm{Fe}(\mathrm{III})$ oxides may be attributed to $\mathrm{Fe}$ isotope fractionation during partial $\mathrm{Fe}(\mathrm{II})$ oxidation and $\mathrm{Fe}(\mathrm{III})$ oxide precipitation (Egal et al., 2008).

Partial extraction of pore fluid-free sediment for $1 \mathrm{~h}$ with $0.1 \mathrm{M} \mathrm{HCl}$ was used to isolate solid-phase $\mathrm{Fe}(\mathrm{II})\left[\mathrm{Fe}(\mathrm{II})_{\mathrm{s}}\right.$, which was likely a mixture of sorbed $\mathrm{Fe}(\mathrm{II})$ and amorphous 
ᄂ

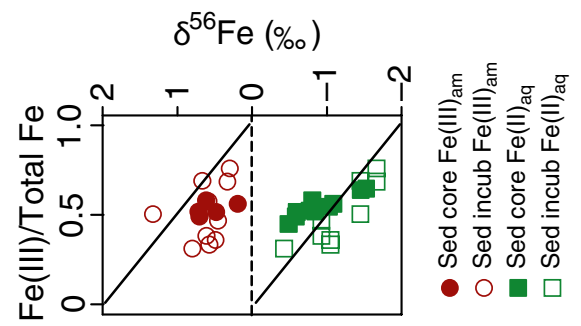

$\boldsymbol{\omega}$

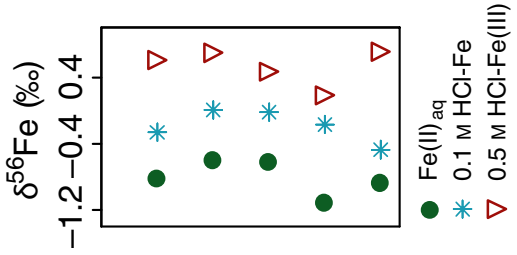

口

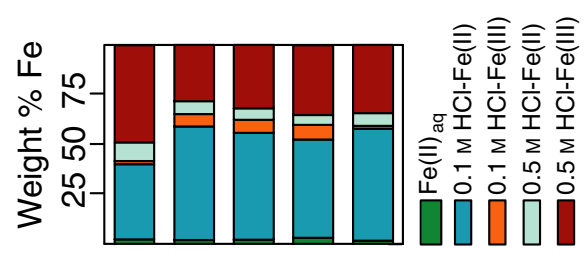

0
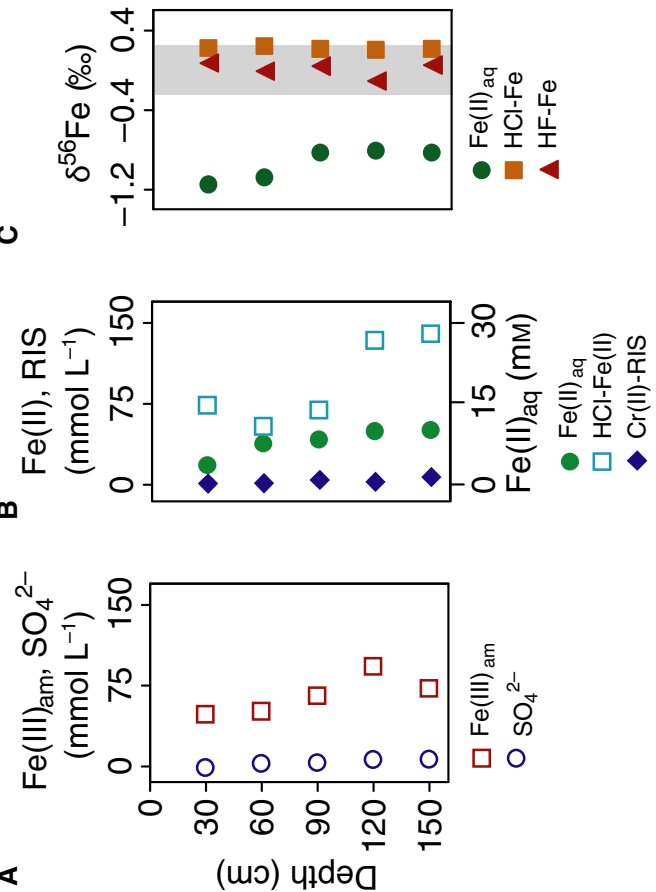

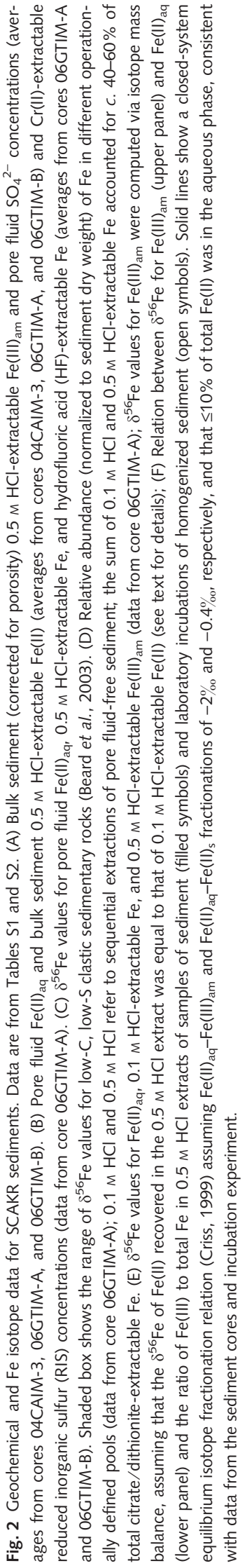


surface-precipitated $\mathrm{Fe}(\mathrm{II})$ hydroxide (Roden \& Edmonds, 1997). $\mathrm{Fe}(\mathrm{II})$ accounted for $>85 \%$ of total $\mathrm{Fe}$ in the $0.1 \mathrm{M}$ $\mathrm{HCl}$ extracts (Fig. 2D; see also Table S2). Subsequent 24-h extraction with $0.5 \mathrm{M} \mathrm{HCl}$ recovered $\mathrm{Fe}(\mathrm{III})_{\mathrm{am}}$ (Fig. 2D) plus some residual $\mathrm{Fe}(\mathrm{II})_{s}$. The $\mathrm{Fe}$ isotope composition of the $\mathrm{Fe}(\mathrm{III})_{\mathrm{am}}$ component in each depth interval was estimated by assuming that $\mathrm{Fe}(\mathrm{II})$ in the $0.5 \mathrm{M} \mathrm{HCl}$ extract had a $\delta^{56} \mathrm{Fe}$ value equal to the $\mathrm{Fe}$ in the $0.1 \mathrm{M} \mathrm{HCl}$ extract for that depth interval. This approach assumes that partial dissolution of mixed $\mathrm{Fe}(\mathrm{III}) / \mathrm{Fe}(\mathrm{II})$ solids does not cause $\mathrm{Fe}$ isotope fractionation, which is consistent with (i) previous studies that have demonstrated that partial dissolution of $\mathrm{Fe}(\mathrm{III})$ oxides by dilute $\mathrm{HCl}$ does not lead to $\mathrm{Fe}$ isotope fractionation (Skulan et al., 2002; Wiederhold et al., 2006); (ii) the consistency of the solid-phase $\mathrm{Fe}(\mathrm{II})-\mathrm{Fe}$ (III) isotope fractionation observed here and in previous studies (Crosby et al., 2005, 2007); and (iii) the lack of correlation between the $0.1 \mathrm{M}$ and $0.5 \mathrm{M} \mathrm{HCl}$-extractable $\mathrm{Fe}$ isotope compositions and the proportion of $\mathrm{Fe}(\mathrm{II})$ recovered in the $0.5 \mathrm{M} \mathrm{HCl}$ extraction $\left(r^{2}=0.01, n=16\right.$ including data from the laboratory sediment incubation discussed below). Isotopic mass balance would require such a correlation if $\mathrm{Fe}$ isotopes were systematically fractionated during partial $\mathrm{HCl}$ dissolution.

The observed trends in Fe isotope fractionations between $\mathrm{Fe}(\mathrm{II})_{\mathrm{aq}}, \mathrm{Fe}(\mathrm{II})_{\mathrm{s}}$, and $\mathrm{Fe}(\mathrm{III})_{\mathrm{am}}$ (Fig. 2E) are similar to those measured in pure culture DIR experiments with crystalline $\mathrm{Fe}$ (III) oxides, in which equilibrium $\mathrm{Fe}$ isotope exchange between biogenic $\mathrm{Fe}(\mathrm{II})$ and $0.5 \mathrm{M} \mathrm{HCl}$-soluble $\mathrm{Fe}(\mathrm{III})$ oxide mineral surface atoms has been identified as the mechanism for generation of isotopically light $\mathrm{Fe}$ (II) (Crosby et al., $2005,2007)$. Isotopic exchange between $\mathrm{Fe}(\mathrm{II})$ and bulk $\mathrm{Fe}(\mathrm{III})_{\mathrm{am}}$ is likely responsible for generation of low $-\delta^{56} \mathrm{Fe}$ aqueous $\mathrm{Fe}(\mathrm{II})$ in SCAKR sediments, as there was a direct correlation between the $\delta^{56} \mathrm{Fe}$ of $\mathrm{Fe}(\mathrm{II})_{\mathrm{aq}}\left(\delta^{56} \mathrm{Fe}_{\mathrm{Fe}(\mathrm{II}) \mathrm{aq}}\right)$ and the ratio of $\mathrm{Fe}$ (III) to total $0.5 \mathrm{M} \mathrm{HCl}$-extractable $\mathrm{Fe}\left(\mathrm{Fe}_{\mathrm{Tot}}\right)$

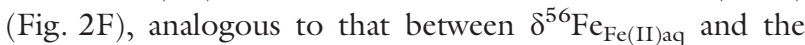
ratio of $\mathrm{Fe}(\mathrm{III})$ to total $\mathrm{Fe}$ in $0.5 \mathrm{M} \mathrm{HCl}$-soluble Fe in crystalline $\mathrm{Fe}(\mathrm{III})$ oxide reduction experiments (see fig. 10 in Crosby et al., 2007).

A laboratory experiment was conducted to confirm the ability of indigenous DIRMs to produce the measured Fe isotope compositions in SCAKR sediments. Incubation of oxidized sediment under anaerobic conditions (Fig. 3) produced trends in Fe redox speciation and isotope compositions analogous to those observed in situ, i.e. Fe(III) reduction produced $\mathrm{mM}$ concentrations of isotopically light $\mathrm{Fe}(\mathrm{II})_{\mathrm{aq}}$ and rendered the residual $\mathrm{Fe}(\mathrm{III})_{\text {am }}$ pool slightly (but detectably) heavy relative to the bulk sediment $\delta^{56} \mathrm{Fe}$ value of $\sim 0 \%$. Collectively, the data suggest an equilibrium $\mathrm{Fe}$ isotope fractionation between $\mathrm{Fe}(\mathrm{II})_{\mathrm{aq}}$ and $\mathrm{Fe}(\mathrm{III})_{\mathrm{am}}$ on the order of $-2 \%$, and a smaller but significant fractionation between $\mathrm{Fe}(\mathrm{II})_{\mathrm{aq}}$ and $\mathrm{Fe}(\mathrm{II})_{\mathrm{s}}$ of $-0.4 \%$ (Fig. 2E,F). Both of these values are comparable, though not identical, to results obtained in laboratory DIR experiments with synthetic $\mathrm{Fe}(\mathrm{III})$ oxides and pure
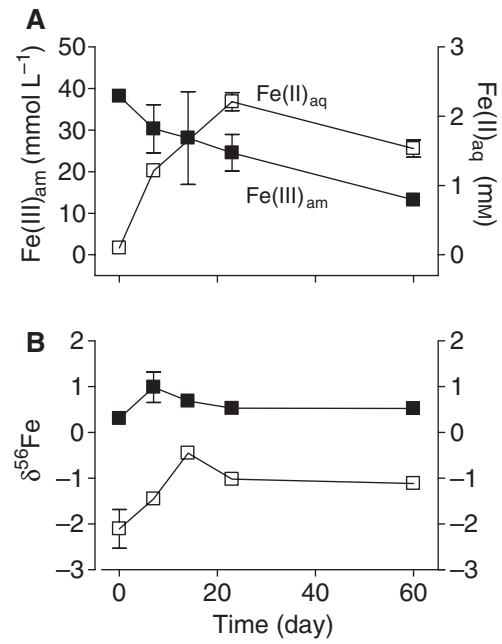

Fig. 3 Changes in Fe redox speciation (A) and Fe isotope composition (B) during laboratory incubation of sediment from $\sim 150 \mathrm{~cm}$ depth (see Materials and methods). Data points represent the mean \pm range of duplicate sediment suspensions.

DIRMs cultures (Crosby et al., 2005, 2007; Johnson et al., 2005; Wu et al., 2009). The fact that the observed Fe(II) $)_{\mathrm{aq}}-$ $\mathrm{Fe}(\mathrm{III})_{\mathrm{am}}$ fractionation is less negative (by c. $1 \%$ ) than that documented for $\mathrm{Fe}(\mathrm{II})_{\mathrm{aq}}$ and $\mathrm{Fe}(\mathrm{III})_{\mathrm{aq}}$ in solution (Welch et al., 2003), and for $\mathrm{Fe}(\mathrm{II})_{\mathrm{aq}}$ and surface $\mathrm{Fe}(\mathrm{III})$ atoms on hematite (Crosby et al., 2005, 2007), may reflect the smaller $\mathrm{Fe}(\mathrm{II})_{\mathrm{aq}}$-goethite $\mathrm{Fe}$ isotope fractionation factor relative to $\mathrm{Fe}(\mathrm{II})_{\mathrm{aq}}$-hematite (Beard et al., 2009), as well as potential differences in $\mathrm{Fe}(\mathrm{II})$ and $\mathrm{Fe}(\mathrm{III})$ bonding in complex DIR systems (Wu et al., 2009).

The $\delta^{56} \mathrm{Fe}_{\mathrm{Fe}(\mathrm{II}) \text { aq }}$ values in SCAKR sediments $(-0.8 \%$ o to $-1.2 \%$ ) are less negative than those documented for the surficial $\mathrm{Fe}(\mathrm{III})$-reducing zone of modern marine sediments $(-1.3 \%$ to $-3 \%$ ) (Bergquist \& Boyle, 2006; Severmann et al., 2006; Homoky et al., 2009), or stratified water columns (Teutsch et al., 2009). This contrast is probably related to differences in Fe redox cycling and redistribution, processes that concentrate on isotopically light $\mathrm{Fe}$ (both aqueous and solid-phase) near the aerobic-anaerobic interface (Staubwasser et al., 2006). In modern marine sediments, for example, near-surface oxidation of low- $\delta^{56} \mathrm{Fe}$ aqueous $\mathrm{Fe}(\mathrm{II})$ produces low- $\delta^{56} \mathrm{Fe}$ reactive $\mathrm{Fe}(\mathrm{III})$ oxides, which, when partially reduced by DIRMs, may produce $\mathrm{Fe}(\mathrm{II})_{\text {aq }}$ that has very low $\delta^{56} \mathrm{Fe}$ values (Severmann et al., 2006; Homoky et al., 2009). The extremely rapid and voluminous deposition of $\mathrm{Fe}(\mathrm{III})_{\mathrm{am}}$ in the SCAKR probably limited the extent of Fe redox cycling and redistribution at this site. Likewise, the high depositional rates and slightly subneutral $\mathrm{pH}$ (6.2-6.5) has prevented conversion of $\mathrm{Fe}(\mathrm{II})$ to commonly observed end products of microbial $\mathrm{Fe}(\mathrm{III})_{\text {am }}$ reduction such as magnetite and siderite (Walker, 1984), neither of which were detected by XRD nor transmission electron microscopic analysis (see Figs. S3 and S4). 


\section{Implications for BIF genesis in the Archean and Paleoproterozoic}

Most models for BIF formation involve two stages: an initial water column stage during which hydrothermally sourced $\mathrm{Fe}(\mathrm{II})_{\mathrm{aq}}$ is oxidized in the photic zone of the oceans, resulting in deposition of $\mathrm{Fe}$ (III) oxides to the seafloor; followed by a sediment diagenetic stage where $\mathrm{Fe}(\mathrm{II})_{\text {aq }}$ reacts with deposited $\mathrm{Fe}$ (III) oxides to produce magnetite [or mixed $\mathrm{Fe}(\mathrm{II})-\mathrm{Fe}(\mathrm{III})$ hydroxide magnetite precursor phases], or with carbonate or dissolved silica to produce siderite or $\mathrm{Fe}(\mathrm{II})$-bearing silicate phases (e.g. Klein, 2005; Beukes \& Gutzmer, 2008). Partial oxidation of hydrothermal $\mathrm{Fe}(\mathrm{II})$ will produce positive $\delta^{56} \mathrm{Fe}$ values for $\mathrm{Fe}(\mathrm{III})$ oxide precipitates, whereas complete oxidation will produce $\delta^{56} \mathrm{Fe}$ values in the precipitates that match those of the source Fe(II) (e.g. Bullen et al., 2001; Rouxel et al., 2003, 2008; Severmann et al., 2004). Positive $\delta^{56} \mathrm{Fe}$ values for oxide minerals in BIFs are generally accepted to reflect partial oxidation of aqueous $\mathrm{Fe}$ (II) (Johnson et al., 2003; Dauphas et al., 2004; Rouxel et al., 2005; Dauphas et al., 2007a,b; Frost et al., 2007; Whitehouse \& Fedo, 2007; Johnson et al., 2008b; Valaas-Hyslop et al., 2008; Planavsky et al., 2009; Steinhoefel et al., 2009). Extensive oxidation of $\mathrm{Fe}(\mathrm{II})_{\mathrm{aq}}$ produces low $-\delta^{56} \mathrm{Fe}$ values in the remaining $\mathrm{Fe}(\mathrm{II})$ (Bullen et al., 2001; Croal et al., 2003; Balci et al., 2006; Rouxel et al., 2008). Coupling of biotic and/or abiotic Fe(II) oxidation to deposition of positive $\delta^{56} \mathrm{Fe} \mathrm{Fe}$ (III) oxides in continental margin sediments could have shifted $\mathrm{Fe}(\mathrm{II})_{\mathrm{aq}}$ in deep anoxic basin waters to negative $\delta^{56} \mathrm{Fe}$ values, leading to the eventual burial of low- $\delta^{56} \mathrm{Fe}$ pyrite (Rouxel et al., 2005). However, this process cannot account for the formation of low- $\delta^{56} \mathrm{Fe}$ magnetite and siderite in Fe-rich sediments such as BIFs, because the amount of low- $\delta^{56} \mathrm{Fe} F e(I I)_{\text {aq }}$ generated during extensive $\mathrm{Fe}(\mathrm{II})_{\text {aq }}$ oxidation is relatively small (see fig. 1 in Johnson et al., 2008a). As recently suggested by Steinhoefel et al. (2009), strata within BIF deposits that form during input of relatively low amounts of Fe are likely to be dominated by chert as opposed to Fe minerals. The key implication of this is that the production of relatively small amounts of low- $\delta^{56} \mathrm{Fe}$ $\mathrm{Fe}(\mathrm{II})_{\mathrm{aq}}$ during near-complete oxidation of $\mathrm{Fe}(\mathrm{II})$ in the water column is not likely to have led to the formation of Fe-rich, low $-\delta^{56} \mathrm{Fe}$ rocks. An alternative process for producing large quantities of low- $\delta^{56} \mathrm{Fe}$ aqueous $\mathrm{Fe}(\mathrm{II})$ is required.

$\mathrm{Fe}(\mathrm{III})$ oxide deposits associated with modern hydrothermal vent systems (e.g. Bonatti \& Joensuu, 1966; Karl et al., 1988; Rouxel et al., 2003; Severmann et al., 2004) may be considered as analogs to the first stage of BIF formation. They are not, however, complete BIF analogs because they do not account for the significant inventory of $\mathrm{Fe}(\mathrm{II})$ in BIF minerals such as magnetite and siderite. In addition, such deposits are not connected to carbon-cycling processes in a manner analogous to widely accepted models for BIF genesis, in which photosynthesis (oxygenic or anoxygenic)-driven $\mathrm{Fe}(\mathrm{II})$ oxidation led to codeposition of $\mathrm{Fe}(\mathrm{III})$ oxides and organic matter that served as substrates for DIR (Walker, 1984, 1987; Kappler et al., 2005; Konhauser et al., 2005). DIR provides an explanation for the large inventory of $\mathrm{Fe}$ (II) in BIFs, as well as the highly negative $\delta^{13} \mathrm{C}$ values for BIF carbonates that have been interpreted to record oxidation of photosynthetically derived organic matter (Becker \& Clayton, 1972; Walker, 1984; Baur et al., 1985; Beukes \& Gutzmer, 2008; Fischer et al., 2009).

The initial end product of DIR is aqueous Fe(II), which is likely to have been present in relatively high concentrations in $\mathrm{Fe}(\mathrm{III})$-reducing BIF precursor sediments. Because the aqueous $\mathrm{Fe}(\mathrm{II})$ component is not preserved in ancient rocks such as BIFs, modern systems are needed to understand the potential mechanisms that can produce $\mathrm{Fe}(\mathrm{II})$-bearing BIF minerals, in particular those with low $\delta^{56} \mathrm{Fe}$ values. Studies in modern continental margin sediments have provided important information on how DIR could have caused Fe isotope fractionation during early diagenesis in ancient marine sediments (Severmann et al., 2006). However, Fe transformation in these sediments is influenced by interactions with sulfur to a much greater extent than was the case in S-poor BIF precursor sediments.

The SCAKR site provides insight into the role of $\mathrm{Fe}(\mathrm{II})_{\mathrm{aq}}$ in BIF genesis that cannot be determined from the rock record because aqueous components are lost upon lithification. The site is an analog to relatively shallow-water shelf environments in which near-complete oxidation of incoming, hydrothermally sourced $\mathrm{Fe}$ (II) [resulting in the deposition of near-zero $\delta^{56} \mathrm{Fe} \mathrm{Fe}(\mathrm{III})$ oxides] may have taken place in conjunction with oxygenic or anoxygenic photosynthesis, leading to codeposition of $\mathrm{Fe}$ (III) oxides and modest amounts of labile organic matter whose oxidation fueled DIR activity. High concentrations of $\mathrm{Fe}(\mathrm{III})_{\mathrm{am}}$ would have suppressed DSR and allow DIR to dominate sediment Fe diagenesis in a manner analogous to that inferred for BIFs (Walker, 1984). In essence, this scenario corresponds to that envisioned by Severmann et al. (2008) based on solid-phase Fe isotope analyses on Black Sea sediments, in which DIR in continental shelf sediments is responsible for the mobilization of isotopically light $\mathrm{Fe}$ that is eventually captured in pyrite in deep euxinic basin shale deposits. This benthic Fe shuttle model provides a mechanism for producing bulk changes in $\delta^{56} \mathrm{Fe}$ values of marine sedimentary rocks. In addition, as noted in Johnson et al. (2008a), DIR driven by sustained burial flux of Fe(III) oxide and organic carbon can create a continual source of low$\delta^{56} \mathrm{Fe} \mathrm{Fe}(\mathrm{II})$, which by diffusion or other transport processes could result in large-scale $\mathrm{Fe}$ isotope redistribution across sediment layers (Ewers, 1983). The work presented here extends this model by documenting production by DIR of very high concentrations of isotopically light $\mathrm{Fe}(\mathrm{II})_{\mathrm{aq}}$ in pore fluids, analogous to $\mathrm{Fe}(\mathrm{II})_{\mathrm{aq}}$-rich pore fluids in modern marine sediments that have been inferred, but not proven, to have been produced by DIR (Bergquist \& Boyle, 2006; Severmann et al., 2006; Rouxel et al., 2008). 
We stress that the SCAKR sediment is envisioned as an analog to the earliest stages of near-surface BIF diagenesis, where aqueous $\mathrm{Fe}(\mathrm{II})$ interacted with ferric oxide/hydroxides or precipitated $\mathrm{Fe}(\mathrm{II})$-bearing minerals from solution. Later diagenetic and authigenic mineral formation pathways are required to produce the minerals observed in BIFs, including dewatering/compaction and modest heating, ultimately leading to the formation of consolidated magnetite- and/or siderite-rich layered deposits (Klein, 2005). This is consistent with most models for BIF formation, where poorly crystalline silica, aqueous $\mathrm{Fe}(\mathrm{II})$, and $\mathrm{Fe}(\mathrm{III})$ oxide in fluid-rich gels are envisioned to be precursors to chert, magnetite, siderite, and $\mathrm{Fe}(\mathrm{II})$ silicates (e.g. Klein, 2005; Beukes \& Gutzmer, 2008).

Figure 4 presents conceptual depictions of how the production of isotopically light $\mathrm{Fe}(\mathrm{II})$ by DIR in such sediments

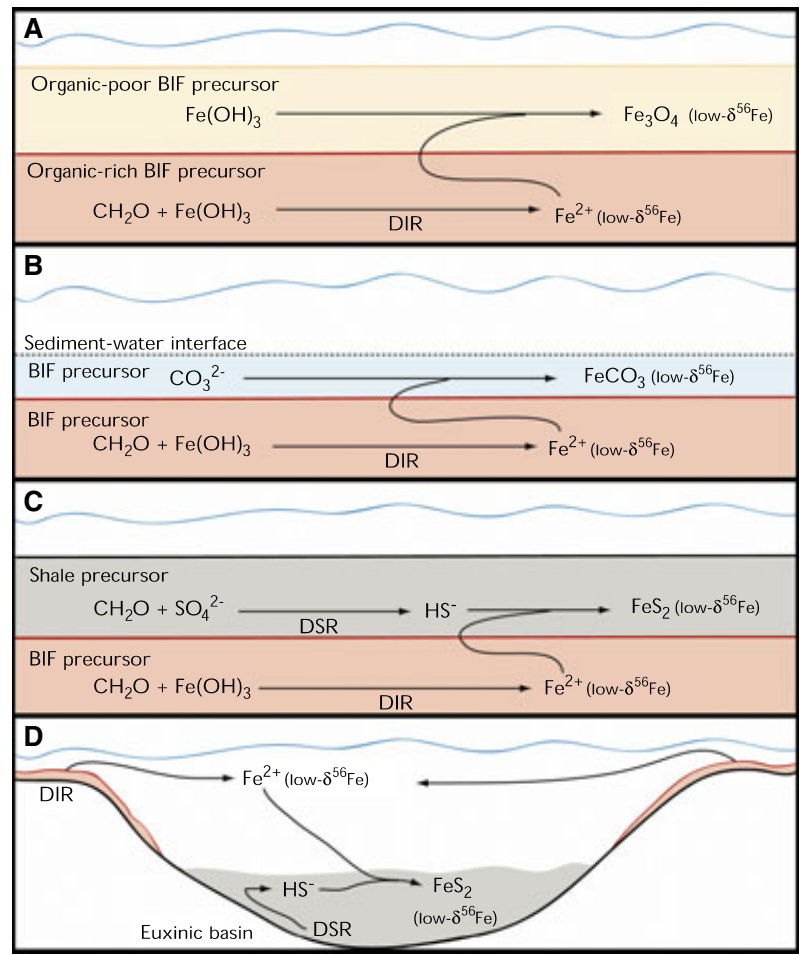

Fig. 4 Conceptual models for how production and transport (via diffusion/ dispersion or advection) of low- $\delta^{56} \mathrm{Fe}$ aqueous Fe(II) by DIR in BIF precursor sediments could have led to generation of low $-\delta^{56} \mathrm{Fe}$ magnetite, siderite, and pyrite in Archean and Paleoproterozoic rocks. Note that the Fe(III) oxides undergoing reduction are presumed to have originated from near-complete oxidation of hydrothermally derived Fe(II) in the water column. (A) Transport from organic-rich sediments (active DIR) to organic-poor sediments (little or no $\mathrm{DIR}$ ) and reaction with $\mathrm{Fe}(\mathrm{III})_{\mathrm{am}}$ to form isotopically light magnetite via solidstate conversion (Hansel et al., 2003). (B) Transport to the sediment-water interface followed by reaction with dissolved carbonate to form a layer of low$\delta^{56} \mathrm{Fe}$ siderite. (C) Transport into an organic-rich siliciclastic layer supporting DSR and reaction with sulfide to produce low- $\delta^{56} \mathrm{Fe}$ pyrite (Archer \& Vance, 2006; Severmann et al., 2006). (D) Release from continental margin sediments, followed by transport into an adjacent deep euxinic basin and reaction with sulfide to form low- $\delta^{56} \mathrm{Fe}$ pyrite (Severmann et al., 2008). could eventually lead to the formation of major BIF minerals such as magnetite and siderite, as well as sedimentary pyrite, which may have negative $\delta^{56} \mathrm{Fe}$ values in the range of those observed in BIFs and black shales (see Fig. 1B). This model assumes implicitly that the $\mathrm{Fe}(\mathrm{III})$ oxides undergoing reduction were first produced by near-complete oxidation of hydrothermally derived $\mathrm{Fe}$ (II) (in the water column) that had a $\delta^{56} \mathrm{Fe}$ value close to zero. In all cases, partial reduction of $\mathrm{Fe}(\mathrm{III})_{\mathrm{am}}$ is the mechanism responsible for mobilization of low- $\delta^{56} \mathrm{Fe}$ aqueous $\mathrm{Fe}(\mathrm{II})$, which is subsequently transported away from the locus of DIR and eventually incorporated into $\mathrm{Fe}(\mathrm{II})$-bearing minerals. It must be emphasized that the processes depicted in Fig. 4 are not meant to imply periodicity or to explain the formation of different types of banding structures present in BIFs, but rather simply to illustrate how isotopically light $\mathrm{Fe}(\mathrm{II})$ may be mobilized by DIR and later incorporated into such layered deposits that reflect authigenic mineral formation prior to lithification.

A key question that arises from the above conceptual model is the fate of the isotopically heavy $\mathrm{Fe}$ (III) oxide left behind after mobilization of low- $\delta^{56} \mathrm{Fe}$ aqueous $\mathrm{Fe}(\mathrm{II})$. Recent work on siderite-bearing BIF strata from the Kuruman Iron Formation and underlying BIF and platform $\mathrm{Ca}-\mathrm{Mg}$ carbonates of the Gamohaan Formation in South Africa (Heimann et al., 2010) has documented the presence, in some strata, of low$\delta^{13} \mathrm{C}$, high- $\delta^{56} \mathrm{Fe}$ siderite that are likely to have formed by near-complete reduction by DIR of high- $\delta^{56} \mathrm{Fe} \mathrm{Fe(III)} \mathrm{oxides}$ that were left over from prior partial $\mathrm{Fe}(\mathrm{III})$ reduction by DIR. An interesting related observation is the common occurrence of hematite inclusions in the high- $\delta^{56} \mathrm{Fe}$ siderite-bearing strata, which may represent small amounts of residual crystalline $\mathrm{Fe}(\mathrm{III})$ oxide that remained resistant to microbial reduction. The combined $\mathrm{Fe}, \mathrm{C}$, and $\mathrm{O}$ isotope data from the Heimann et al.'s (2010) study are consistent with the conceptual model in Fig. 4, in which differential Fe mobilization by DIR, prior to lithification, plays a key role in determining the range of $\delta^{56} \mathrm{Fe}$ values of BIF mineral phases. On a basin-wide scale, Czaja et al. (2010) note that low- $\delta^{56} \mathrm{Fe}$ values for black shales in the central part of the 2.7-Ga Hamersley basin were balanced by slightly positive values for coeval sediments on the margin of the basin, consistent with the benthic Fe shuttle model of Severmann et al. (2008). These observations emphasize the key issue of basin-scale isotope mass balance in interpreting the Fe isotope composition of ancient rocks. All of these results support previous (Walker, 1984) and ongoing (Vargas et al., 1998; Johnson et al., 2008a) inferences regarding the prominence of DIR in sediment biogeochemical cycling on the early Earth.

\section{ACKNOWLEDGEMENTS}

This research was funded by the NASA Astrobiology Institute (University of California-Berkeley and University of Wisconsin-Madison nodes) and the National Science Foundation 
(Biogeosciences Program Award 0525417). Logistical support for field sampling was provided by the US Geological Survey in cooperation with the US Environmental Protection Agency. We thank Kurt Konhauser and three anonymous reviewers whose thoughtful criticism substantially improved the manuscript.

\section{REFERENCES}

Alpers CN, Antweiler RC, Taylor HE, Dileanis PD, Domagalski JL (2000) Metals Transport in the Sacramento River, California, 1996-1997, Volume 2: Interpretation of Metal Loads. US Geological Survey Water-Resources Investigation Report, Sacramento, CA, pp. $99-4286$.

Alpers CN, Nordstrom DK, Spitzley J (2003) Extreme acid mine drainage from a pyritic massive sulfide deposit: the Iron Mountain end member. In Environmental Aspects of Mine-Wastes (eds Jambor JL, Blowes DW, Ritchie AIM). Mineralogical Association of Canada, Ottawa, pp. 407-430.

Archer C, Vance D (2006) Couple Fe and S isotope evidence for Archean microbial Fe(III) and sulfate reduction. Geology 34, $153-156$

Balci N, Bullen TD, Witte- Lien K, Shanks WC, Motelica M, Mandernack KW (2006) Iron isotope fractionation during microbially stimulated $\mathrm{Fe}(\mathrm{II})$ oxidation and $\mathrm{Fe}(\mathrm{III})$ precipitation. Geochimica et Cosmochimica Acta 70, 622-639.

Baur ME, Hayes JM, Studley SA, Walter MR (1985) Millimeter-scale variations of stable isotope abundances in carbonates from banded iron-formations in the Hamersley Group of Western-Australia. Economic Geology 80, 270-282.

Beard BL, Johnson CM (2004) Fe isotope variations in the modern and ancient earth and other planetary bodies. In Geochemistry of Non-Traditional Stable Isotopes, Reviews in Mineralogy and Geochemistry 55 (eds Johnson CM, Beard BL, Albarede F). Mineralogical Society of America, Washington, DC, pp. 319-357.

Beard BL, Johnson CM, Cox L, Sun H, Nealson KH, Aguilar C (1999) Iron isotope biosignatures. Science 285, 1889-1891.

Beard BL, Johnson CM, Skulan JL, Nealson KH, Cox L, Sun H (2003) Application of Fe isotopes to tracing the geochemical and biological cycling of Fe. Chemical Geology 195, 85-117.

Beard BL, Handler R, Johnson CM, Scherer M (2009) Experimental determination of the $\mathrm{Fe}$ isotope fractionation between $\mathrm{Fe}(\mathrm{II})$ and goethite. Geochimica et Cosmochimica Acta 73, A99.

Becker RH, Clayton RN (1972) Carbon isotopic evidence for the origin of a banded iron-formation in Western Australia. Geochimica et Cosmochimica Acta 36, 577-595.

Bergquist BA, Boyle EA (2006) Iron isotopes in the Amazon River system: weathering and transport signatures. Earth and Planetary Science Letters 248, 54-68.

Berner RA (1982) Burial of organic carbon and pyrite sulfur in the modern ocean: its geochemical and environmental significance. American Journal of Science 282, 451-473.

Beukes NJ, Gutzmer J (2008) Origin and paleoenvironmental significance of major iron formations at the Archean-Paleoproterozoic boundary. Reviews in Economic Geology Series 15, 5-47.

Bonatti E, Joensuu O (1966) Deep-sea iron deposit from south pacific. Science 154, 643 .

Bullen TD, White AF, Childs CW, Vivit DV, Schulz MS (2001) Demonstration of significant abiotic iron isotope fractionation in nature. Geology 29, 699-702.

Canfield DE (1989) Reactive iron in marine sediments. Geochimica et Cosmochimica Acta 53, 619-632.
Canfield DE (1998) A new model for proterozoic ocean chemistry. Nature 396, 450-661.

Canfield DE (2001) Biogeochemistry of sulfur isotopes. In Stable Isotope Geochemistry, Reviews in Mineralogy and Geochemistry 43 (eds Valley JW, Cole DR). Mineralogical Society of America, Washington, DC, pp. 607-636.

Cline JD (1969) Spectrophotometric determination of hydrogen sulfide in natural waters. Limnology and Oceanography 14, 454-458.

Cloud P (1974) Evolution of ecosystems. American Scientist 62, 54-66.

Criss RE (1999) Principles of Stable Isotope Distribution. Oxford University Press, New York.

Croal LR, Johnson CM, Beard BL, Newman DK (2003) Iron isotope fractionation by anoxygenic $\mathrm{Fe}$ (II)-phototrophic bacteria. Geochimica et Cosmochimica Acta 68, 1227-1242.

Crosby HA, Johnson CM, Roden EE, Beard BL (2005) Fe(II)$\mathrm{Fe}$ (III) electron/atom exchange as a mechanism for Fe isotope fractionation during dissimilatory iron oxide reduction. Environmental Science and Technology 39, 6698-6704.

Crosby HA, Johnson CM, Beard BL, Roden EE (2007) The mechanisms of iron isotope fractionation produced during dissimilatory $\mathrm{Fe}(\mathrm{III})$ reduction by Shewanella putrefaciens and Geobacter sulfurreducens. Geobiology 5, 169-189.

Czaja AD, Johnson CM, Beard BL, Eigenbrode JL, Freeman KH, Yamaguch KE (2010) Iron and carbon isotope evidence for ecosystem and environmental diversity in the $\sim 2.7$ to 2.5 Ga Hamersley Province, Western Australia. Earth and Planetary Science Letters 292, 170-180

Dauphas N, van Zuilen M, Wadhwa M, Davis AM, Marty B, Janney PE (2004) Clues from Fe isotope variations on the origin of early Archean BIFs from Greenland. Science 306, 2077-2080.

Dauphas N, Cates NL, Mojzsis SJ, Busigny V (2007a) Identification of chemical sedimentary protoliths using iron isotopes in the $>3750$ Ma Nuvvuagittuq supracrustal belt, Canada. Earth and Planetary Science Letters 254, 358-376.

Dauphas N, Van Zuilen M, Busigny V, Lepland A, Wadhwa M, Janney PE (2007b) Iron isotope, major and trace element characterization of early Archean supracrustal rocks from SW Greenland: protolith identification and metamorphic overprint. Geochimica et Cosmochimica Acta 71, 4745-4770.

Edwards KJ, Gihring TM, Banfield JF (1999) Seasonal variations in microbial populations and environmental conditions in an extreme acid mine drainage environment. Applied and Environmental Microbiology 65, 3627-3632.

Egal M, Elbaz-Poulichet F, Casiot C, Motelica-Heino M, Negrel P, Bruneel O, Sarmiento AM, Nieto JM (2008) Iron isotopes in acid mine waters and iron-rich solids from the Tinto-Odiel Basin (Iberian Pyrite Belt, Southwest Spain). Chemical Geology 253, 162171.

Ewers WE (1983) Chemical factors in the deposition and diagenesis of banded iron-formations. In Iron-Formation: Facts and Problems (eds Trendall AF, Morris RC). Elsevier, Amsterdam, pp. 491-512.

Ewers WE, Morris RC (1981) Studies of the Dales-Gorge-member of the Brockman-Iron-Formation, Western Australia. Economic Geology 76, 1929-1953.

Farquhar J, Peters M, Johnston DT, Strauss H, Masterson A, Wiechert U, Kaufman AJ (2007) Isotopic evidence for Mesoarchaean anoxia and changing atmospheric sulphur chemistry. Nature 449 , 706-709

Fehr MA, Andersson PS, Halenius U, Morth CM (2008) Iron isotope variations in Holocene sediments of the Gotland Deep, Baltic Sea. Geochimica et Cosmochimica Acta 72, 807-826. 
Fischer WW, Schroeder S, Lacassie JP, Beukes NJ, Goldberg T, Strauss H et al. (2009) Isotopic constraints on the Late Archean carbon cycle from the Transvaal Supergroup along the western margin of the Kaapvaal Craton, South Africa. Precambrian Research 169, 15-27.

Frost CD, von Blanckenburg F, Schoenberg R, Frost BR, Swapp SM (2007) Preservation of $\mathrm{Fe}$ isotope heterogeneities during diagenesis and metamorphism of banded iron formation. Contributions to Mineralogy and Petrology 153,211-235.

Habicht KS, Gade M, Thamdrup B, Berg P, Canfield DE (2002) Calibration of sulfate levels in the Archean Ocean. Science 298, 2372 2374.

Hansel CM, Benner SG, Neiss J, Dohnalkova A, Kukkadapu RK, Fendorf S (2003) Secondary mineralization pathways induced by dissimilatory iron reduction of ferrihydrite under advective flow. Geochimica et Cosmochimica Acta 67, 2977-2992.

Heimann A, Johnson CM, Beard BL, Valley JW, Roden EE, Spicuzza MJ, Beukes NJ (2010) Fe, C, and O isotope compositions of banded iron formation carbonates demonstrate a major role for dissimilatory iron reduction in $\sim 2.5$ Ga marine environments. Earth and Planetary Science Letters. doi:10.1016/j.epsl.2010.02.015.

Homoky WB, Severmann S, Mills RA, Statham PJ, Fones GR (2009) Pore-fluid Fe isotopes reflect the extent of benthic Fe redox recycling: evidence from continental shelf and deep-sea sediments. Geology 37, 751-754.

Hyslop EV, Valley JW, Johnson CM, Beard BL (2008) The effects of metamorphism on $\mathrm{O}$ and $\mathrm{Fe}$ isotope compositions in the Biwabik Iron Formation, northern Minnesota. Contributions to Mineralogy and Petrology 155, 313-328.

Jenkyns HC, Matthews A, Tsikos H, Erel Y (2007) Nitrate reduction, sulfate reduction, and sedimentary iron isotope evolution during the Cenomanian-Turonian oceanic anoxic event. Paleoceanography 22, PA3208.

Johnson CM, Beard BL, Beukes NJ, Klein C, O’Leary JM (2003) Ancient geochemical cycling in the Earth as inferred from Fe isotope studies of banded iron formations from the Transvaal Craton. Contributions to Mineralogy and Petrology 144, 523-547.

Johnson CM, Beard BL, Roden EE, Newman DK, Nealson KH (2004) Isotopic constraints on biogeochemical cycling of Fe. In Geochemistry of Non-Traditional Stable Isotopes, Reviews in Mineralogy and Geochemistry 55 (eds Johnson CM, Beard BL, Albarède F). Mineralogical Society of America, Washington, DC, pp. 359-408.

Johnson CM, Roden EE, Welch SA, Beard BL (2005) Experimental constraints on $\mathrm{Fe}$ isotope fractionation during magnetite and $\mathrm{Fe}$ carbonate formation coupled to dissimilatory hydrous ferric oxide reduction. Geochimica et Cosmochimica Acta 69, 963-993.

Johnson CM, Beard BL, Roden EE (2008a) The iron isotope fingerprints of redox and biogeochemical cycling in the modern and ancient Earth. Annual Review of Earth and Planetary Sciences 36, 457-493.

Johnson CM, Beard BL, Klein C, Beukes NJ, Roden EE (2008b) Iron isotopes constrain biologic and abiologic processes in banded iron formation genesis. Geochimica et Cosmochimica Acta 72, 151-169.

Kappler A, Pasquero C, Konhauser KO, Newman DK (2005) Deposition of banded iron formations by anoxygenic phototrophic $\mathrm{Fe}(\mathrm{II})$ oxidizing bacteria. Geology 33, 865-868.

Karl DM, McMurtry GM, Malahoff A, Garcia MO (1988) Loihi seamount, Hawaii: a mid-plate volcano with a distinctive hydrothermal system. Nature 335, 532-535.

Kashefi K, Lovley D (2000) Reduction of Fe(III), Mn(IV) and Toxic Metals at $100^{\circ} \mathrm{C}$ by Pyrobaculum islandicum. Applied and Environmental Microbiology 66, 1050-1056.
Kashefi K, Lovley DR (2003) Extending the upper temperature limit for life. Science 301, 934.

Kashefi K, Tor JM, Holmes DE, Van Praagh CVG, Reysenbach AL, Lovley DR (2002) Geoglobus ahangari gen. nov., sp nov., a novel hyperthermophilic archaeon capable of oxidizing organic acids and growing autotrophically on hydrogen with $\mathrm{Fe}$ (III) serving as the sole electron acceptor. International Journal of Systematic and Evolutionary Microbiology 52, 719-728.

Klein C (2005) Some Precambrian banded iron-formations (BIFs) from around the world: their age, geologic setting, mineralogy, metamorphism, geochemistry, and origin. American Mineralogist 90, 1473-1499.

Klein C, Beukes NJ (1989) Geochemistry and sedimentology of a facies transition from limestone to iron-formation deposition in the Early Proterozoic Transvaal Supergroup, South-Africa. Economic Geology 84, 1733-1774.

Konhauser KO, Newman DK, Kappler A (2005) The potential significance of microbial $\mathrm{Fe}(\mathrm{III})$ reduction during deposition of Precambrian banded iron formations. Geobiology 3, 167-177.

Lovley DR (1991) Dissimilatory Fe(III) and Mn(IV) reduction. Microbiological Reviews 55, 259-287.

Lovley DR, Phillips EJP (1987a) Rapid assay for microbially reducible ferric iron in aquatic sediments. Applied and Environmental Microbiology 53, 1536-1540.

Lovley DR, Phillips EJP (1987b) Competitive mechanisms for inhibition of sulfate reduction and methane production in the zone of ferric iron reduction in sediments. Applied and Environmental Microbiology 53, 2636-2641.

Lovley DR, Stolz JF, Nord GL, Phillips EJP (1987) Anaerobic production of magnetite by a dissimilatory iron-reducing microorganism. Nature 330, 252-254.

Lovley DR, Holmes DE, Nevin KP (2004) Dissimilatory Fe(III) and $\mathrm{Mn}(\mathrm{IV})$ reduction. Advances in Microbial Physiology 49, 219-286.

Nealson KH, Myers CR (1990) Iron reduction by bacteria: a potential role in the genesis of banded iron formations. American Journal of Science 290, 35-45.

Nordstrom DK (2000) Advances in the hydrogeochemistry and microbiology of acid mine waters. International Geology Review 42, 499-515.

Nordstrom DK, Alpers CN (1999) Negative pH, efflorescent mineralogy, and consequences for environmental restoration at the Iron Mountain Superfund Site, California. Proceedings of the National Academy of Sciences of the USA 96, 3455-3462.

Nordstrom DK, Alpers CN, Coston JA, Taylor HE, McCleskey RB, Ball JW et al. (1999) Geochemistry, toxicity, and sorption properties of contaminated sediments and pore waters in two reservoirs receiving acid mine drainage from Iron Mountain, California. In Proceedings of the US Geological Survey Toxic Substances Hydrology Program (eds Morganwalp DW, Buxton HT). US Geological Survey Water-Resources Investigation Report, Sacramento, CA, pp. 289-296.

Ohmoto H, Watanabe Y, Ikemi H, Poulson SR, Taylor BE (2006) Sulphur isotope evidence for an oxic Archaean atmosphere. Nature 442, 908-911.

Ono S, Beukes NJ, Rumble D, Fogel ML (2006) Early evolution of atmospheric oxygen from multiple-sulfur and carbon isotope records of the 2.9 Ga Mozaan Group of the Pongola Supergroup, Southern Africa. South African Journal of Geology 109, 97-108.

Planavsky N, Rouxel O, Bekker A, Shapiro R, Fralick P, Knudsen A (2009) Iron-oxidizing microbial ecosystems thrived in late Paleoproterozoic redox-stratified oceans. Earth and Planetary Science Letters 286, 230-242. 
Poulton SW, Fralick PW, Canfield DE (2004) The transition to a sulphidic ocean similar to 1.84 billion years ago. Nature 431 , 173-177.

Raiswell R, Canfield DE (1998) Sources of iron for pyrite formation in marine sediments. American Journal of Science 298, 219-245.

Roden EE, Edmonds JW (1997) Phosphate mobilization in iron-rich anaerobic sediments: microbial $\mathrm{Fe}(\mathrm{III})$ oxide reduction versus ironsulfide formation. Archiv für Hydrobiologie 139, 347-378.

Roden EE, Emerson D (2007) Microbial metal cycling in aquatic environments. In Manual of Environmental Microbiology, 3rd edn (eds Hurst CJ, Lipson D, Crawford R, Garland J, Mills A, Stezenbach LD). American Society for Microbiology, Washington, DC, pp. $540-562$.

Roden EE, Wetzel RG (2002) Kinetics of microbial Fe(III) oxide reduction in freshwater wetland sediments. Limnology and Oceanography 47, 198-211.

Rouxel O, Dobbek N, Ludden J, Fouquet Y (2003) Iron isotope fractionation during oceanic crust alteration. Chemical Geology 202, $155-182$.

Rouxel O, Bekker A, Edwards K (2005) Iron isotope constraints on the Archean and Paleoproterozoic ocean redox state. Science 307, 1088-1091.

Rouxel OJ, Bekker A, Edward KJ (2006) Response to comment on "Iron isotope constraints on the archean and paleoproterozoic ocean redox state". Science 311,177

Rouxel O, Sholkovitz E, Charette M, Edwards KJ (2008) Iron isotope fractionation in subterranean estuaries. Geochimica et Cosmochimica Acta 72, 3413-3430.

Severmann S, Johnson CM, Beard BL, German CR, Edmonds HN, Chiba H, Green DRH (2004) The effect of plume processes on the Fe isotope composition of hydrothermally derived Fe in the deep ocean as inferred from the Rainbow vent site, Mid-Atlantic Ridge, 36 degrees 14' N. Earth and Planetary Science Letters 225, 63-76.

Severmann S, Johnson CM, Beard BL, McManus J (2006) The effect of early diagenesis on the $\mathrm{Fe}$ isotope compositions of porewaters and authigenic minerals in continental margin sediments. Geochimica et Cosmochimica Acta 70, 2006-2022.

Severmann S, Lyons TW, Anbar A, McManus J, Gordon G (2008) Modern iron isotope perspective on the benthic iron shuttle and the redox evolution of ancient oceans. Geology 36, 487-490.

Shelobolina ES, Nevin KP, Blakeney-Hayward JD, Johnsen CV, Plaia TW, Krader P et al. (2007) Geobacter pickeringii sp. nov., Geobacter argillaceus sp. nov. and Pelosinus fermentans gen. nov., sp. nov., isolated from subsurface kaolin lenses. International Journal of Systematic and Evolutionary Microbiology 56, 126-135.

Shen YA, Buick R, Canfield DE (2001) Isotopic evidence for microbial sulphate reduction in the early Archaean era. Nature 410, 77-81.

Skulan JL, Beard BL, Johnson CM (2002) Kinetic and equilibrium Fe isotope fractionation between aqueous $\mathrm{Fe}(\mathrm{III})$ and hematite. Geochimica et Cosmochimica Acta 66, 2995-3015.

Staubwasser M, von Blanckenburg F, Schoenberg R (2006) Iron isotopes in the early marine diagenetic iron cycle. Geology 34, 629-632.

Steinhoefel G, Horn I, von Blanckenburg F (2009) Micro-scale tracing of $\mathrm{Fe}$ and $\mathrm{Si}$ isotope signatures in banded iron formation using femtosecond laser ablation. Geochimica et Cosmochimica Acta 73, $5343-5360$.

Teutsch N, Schmid M, Müller B, Halliday AN, Bürgmann H, Wehrli B (2009) Large iron isotope fractionation at the oxic-anoxic boundary in Lake Nyos. Earth and Planetary Science Letters 285, 52-60.

Thamdrup B (2000) Bacterial manganese and iron reduction in aquatic sediments. Advances in Microbial Ecology 16, 41-84.

Valaas-Hyslop E, Valley JW, Johnson CM, Beard BL (2008) The effects of metamorphism on $\mathrm{O}$ and $\mathrm{Fe}$ isotope compositions in the
Biwabik iron-formation, northern Minnesota. Contributions to Mineralogy and Petrology 155, 313-328.

Vargas M, Kashefi K, Blunt-Harris EL, Lovley DR (1998) Microbiological evidence for $\mathrm{Fe}(\mathrm{III})$ reduction on early Earth. Nature 395, $65-67$.

Walker JCG (1984) Suboxic diagenesis in banded iron formations. Nature 309, 340-342.

Walker JCG (1987) Was the archaean biosphere upside down? Nature 329, 710-712

Welch SA, Beard BL, Johnson CM, Braterman PS (2003) Kinetic and equilibrium $\mathrm{Fe}$ isotope fractionation between aqueous $\mathrm{Fe}(\mathrm{II})$ and Fe(III). Geochimica et Cosmochimica Acta 67, 4231-4250.

Whitehouse MJ, Fedo CM (2007) Microscale heterogeneity of Fe isotopes in $>3.71 \mathrm{Ga}$ banded iron formation from the Isua Greenstone Belt, southwest Greenland. Geology 35, 719-722.

Wiederhold JG, Kraemer SM, Teutsch N, Borer PM, Halliday AN, Kretzschmar R (2006) Iron isotope fractionation during protonpromoted, ligand-controlled, and reductive dissolution of goethite. Environmental Science and Technology 40,3787-3793.

Wu L, Beard BL, Roden EE, Johnson CM (2009) Influence of pH and dissolved $\mathrm{Si}$ on Fe isotope fractionation during dissimilatory microbial reduction of hematite. Geochimica et Cosmochimica Acta 73, 5584-5599.

Yamaguchi KE, Johnson CM, Beard BL, Ohmoto H (2005) Biogeochemical cycling of iron in the Archean-Paleoproterozoic Earth: constraints from iron isotope variations in sedimentary rocks from the Kaapvaal and Pilbara Cratons. Chemical Geology 218, 135169.

Zhabina NN, Volkov II (1978) A method for determination of various sulfur compounds in sea sediment and rocks. In Environmental Biogeochemistry (ed. Krumbein WE). Ann Arbor Science Publishers, Ann Arbor, pp. 735-746.

\section{SUPPORTING INFORMATION}

Additional Supporting Information may be found in the online version of this article:

Fig. S1 (A) Location of study site located in Shasta County, northern California. (B) Tributaries carry acid mine drainage (AMD) from Iron Mountain to the Spring Creek Reservoir.

Fig. S2 Percent of total citrate/dithionite (CD)-extractable Fe soluble in $0.5 \mathrm{M}$ $\mathrm{HCl}(1.5 \mathrm{~g}$ of pore fluid-free sediment in $10 \mathrm{~mL}$ ) over time.

Fig. S3 X-ray diffraction (XRD) analyses of anaerobically dried SCAKR sediment, showing the dominant mineralogy as quartz, kaolinite, and the Fe(III) oxides goethite and ferrihydrite.

Fig. S4 Transmission electron microscopic (TEM) images and selected area electron diffraction (SAED) patterns of anaerobically dried SCAKR sediment showing the presence of goethite $(A, B)$ and ferrihydrite $(C, D)$ form aggregates of nanometer-scale grains. These aggregates were generally associated with clay minerals [smectite (S), kaolinite (K) and halloysite] or feldspar (E, F).

Table S1 Summary of geochemical measurements from SCAKR sediment cores and the sediment incubation experiments.

Table S2 Summary of Fe isotope measurements from SCAKR sediment cores and the sediment incubation experiment. 
Table S3 Abundance of culturable DIRM at $\sim 150 \mathrm{~cm}$ depth in SCAKR core 06GTIM-B

Table S4 Phylogenetic assignments for 16S rRNA gene sequences (64 total) from the SCAKR sediment clone library.
Please note: Wiley-Blackwell is not responsible for the content or functionality of any supporting materials supplied by the authors. Any queries (other than missing material) should be directed to the corresponding author for the article. 